\title{
Shareholder activism in Malaysia: exploring a missing parameter
}

\begin{abstract}
The topic of shareholder activism has become an important issue for discussion in the corporate world, and debate continues to exist with regard to this matter. In the corporate world, the minority shareholders are the least protected corporate participants, due to their minimal voice in corporate decision-making. This paper is not empirically based but merely conceptual. Therefore, it is aimed at presenting the preliminary work for a study. The concepts of corporate governance, ownership structure and control, shareholder-companies relationship and majority-minority shareholders relationship are discussed, in order to gain an understanding of the concept and some practical perspectives of shareholder activism. From the discussion, several missing parameters of shareholder activism were derived. These missing parameters are considered red flags; there is a dire need to conduct further research for a better understanding of this important topic.
\end{abstract}

Keyword: Corporate governance; Shareholder activism; Minority shareholders; Ownership and control; Corporate response component 